\title{
"Check your Smile", prototype of a collaborative LSP website for technical vocabulary
}

\author{
Nadia Yassine-Diab ${ }^{1}$, Charlotte Alazard-Guiu², \\ Mathieu Loiseau ${ }^{3}$, Laurent Sorin ${ }^{4}$, and Charlotte Orliac ${ }^{5}$
}

\begin{abstract}
In a design-based research approach (Barab \& Squire, 2004), we are currently developing the first prototype of a collaborative Language for Specific Purposes (LSP) website. It focuses on technical vocabulary to help students master any field of LSP better. "Check Your Smile" is a platform aggregating various types of gameplays for each of which games are generated, based on the content of a collaboratively-constructed/user-generated multilingual dictionary. To this day the platform integrates six lexical games. In addition, "Check your Smile", as a prototype of a new platform itself, has been selected as an Initiative of Excellence Project from the University of Toulouse in France. In a context of digital game-based learning, and as games, gaming and playing have become one of the main trends in educative innovation, we first justify the choice of a digital game-based learning solution. Then, we present the methodology followed for the development of "Check your Smile" and describe the linguistic and collaborative objectives. Finally, we conclude by presenting the potential future evolutions of our platform, as the release candidate version will be accessible from early 2017 onwards.
\end{abstract}

Keywords: language service provider, game-based digital learning, collaboration, technical vocabulary, Web 2.0, user-generated content, vocabulary learning.

\footnotetext{
1. LAIRDIL, University of Toulouse, Toulouse, France; nadia.yassine-diab@univ-tlse3.fr

2. OCTOGONE-LORDAT, University of Toulouse, Toulouse, France; alazard@univ-tlse2.fr

3. LIDILEM, University of Grenoble Alpes, Grenoble, France; mathieu.loiseau@univ-grenoble-alpes.fr

4. IRIT, University of Toulouse, Toulouse, France; laurent.sorin@irit.fr

5. IRIT, University of Toulouse, Toulouse, France; charlotte.orliac@irit.fr
}

How to cite this article: Yassine-Diab, N., Alazard-Guiu, C., Loiseau, M., Sorin, L., \& Orliac, C. (2016). "Check your Smile", prototype of a collaborative LSP website for technical vocabulary. In S. Papadima-Sophocleous, L. Bradley \& S. Thouësny (Eds), CALL communities and culture - short papers from EUROCALL 2016 (pp. 496-501). Research-publishing.net. https://doi.org/10.14705/rpnet.2016.eurocall2016.613 


\section{Context and choice of a digital game-based solution}

In France, it is mandatory to study at least one foreign language at university, whatever the student's major might be. This may directly impact how students view language learning and how (un)motivated they are to learn a foreign language (Dornyei, 2009). The recent literature shows the positive impact of digital game-based solutions on motivation (e.g. Oblinger, 2004; Papastergiou, 2009; Sharples et al., 2013), hence our choice to develop a game-based collaborative platform. Besides, university language teaching for students is not always adapted to their future linguistic needs in the professional world, which sometimes also contributes to a lack of motivation, hence our choice to focus on technical vocabulary learning. For the past 20 years in France, several LSP teacher associations and research groups (such as the GERAS research group for English for specific purposes, www.geras.fr/) have promoted research in LSP and have contributed to the development and teaching of LSP, showing the positive impact it has on students' motivation and students' preparation to their professional life (Van Der Yeught, 2014). The construct of LSP didactics and in particular of a theoretical framework is still being developed in France (see Sarré \& Whyte, 2016). This reveals an increasing concern for LSP which is of course not limited to terminology but also involves a specific syntax, abbreviations and neologisms for instance. However, in order to both facilitate the professional integration of French students and potentially help increase their motivation to learn LSP vocabulary which is linked to their field of study, we have decided to focus on specialized vocabulary learning as a complementary tool to LSP classes. Indeed, vocabulary is seen as a basic but essential tool without which a specialized technical discourse cannot be built. In a context where Web 2.0 has set the ground for large scale collaborative work, we are currently developing the first multidisciplinary and multilingual platform in France called "Check your Smile" which harnesses the scientific and academic terms of all specific purposes to be acquired by the students. Furthermore, as games, gaming and playing have become one of the strong trends in educative innovation in general (Sharples et al., 2013) and in language learning in particular (Cornillie, Thorne, \& Desmet, 2012), we have adopted a digital game-based learning approach to hopefully trigger and/or sustain the motivation of our students, which is one of the effects of using games in learning (Oblinger, 2004; Papastergiou, 2009). To do so, we have adapted Thiagi's (n.d.) recent Four Door model ${ }^{6}$ and designed three different spaces on the platform: (1) the library (we called it Dictionary)

6. For a visual presentation of Thiagi's Four Door model, see https://iquidinteractive.files.wordpress.com/2013/02/four-doors 1.jpg 
which is an online user-generated dictionary; (2) the playground (we called it Games) where all the games are; and (3) the social interactions part which is what we called Community: this is the space where you can vote on (i.e. assess) other players' submissions and/or complete other players' submissions. The six current games range from audio crosswords to a taboo-like game ${ }^{7}$ or a hangmanlike game; our objective is to allow the student to work on listening and reading, as well as on writing and speaking which are traditionally more difficult to assess in a digital context. However, the integration of games into the learners' activity is not the sole object of our system. Based on the works of Kim (2008), who stresses the importance of collaborative tasks to promote the acquisition of L2 vocabulary, we assume that students will be more involved, as they take part in the content generation process, which in itself can also be motivating (Kessler, 2013). This hypothesis will be tackled during the user tests and after the release of Version 1 next January, using Rabardel's (1995) concept of 'Instrumental genesis' to consider this platform in the context of its future use.

\section{History, methodology and objectives}

"Check your smile" was originally designed in a specific Content and Language Integrated Learning (CLIL) set of classes from a computing department where students had to take computing, maths and economics classes in English, in 2013. Its name stems from this original CLIL experience then called SMILE. It was initially an extra tool in this learning environment. Today, even though the scope has changed as it is meant to be both multidisciplinary and multilingual, the name remained the same. In 2014 and 2015, an interuniversity and interdisciplinary team was set up to rethink a new version of "Check your Smile". It comprised 11 schools and universities, four sites and about 80 people from the University of Toulouse, in addition to national and international collaborations. Then, "Check your Smile" was selected in late 2015 as an Initiative of Excellence Development Project from the University of Toulouse in France (http://www.univ-toulouse.fr/ node/11538). The budget granted early 2016 allows us to redevelop the former 2013 prototypal version in a more professional way, and to experiment with it on our students.

Our international team now collaborates in gathering lexical corpora for specific purposes in different languages (such as French, English, Spanish, or Chinese) and in different fields (such as mechanical engineering, law or design). We first

7. For a presentation of the game 'Taboo', see https://en.wikipedia.org/wiki/Taboo_(game) 
started by breaking down into categories and subcategories the different fields and subfields studied at the University, using both universities' online courses presentations and teachers' feedback.

Our categorization currently comprises more than 400 subfields or technical specialties (e.g. databases) for about 40 fields of study (e.g. computer science). Our team then used this material in the process of providing lexical entries, for its categorization. This step of the project is particularly important in order to obtain a first lexical corpus rich enough to play on the platform at its release, before any further vocabulary can be collaboratively built. This first version of the platform database will then contain entries submitted by our team, as well as science vocabulary from an online corpus called Lexico-Science (http://lexico.unisciel.fr/) whose owners generously agreed for us to use in our project.

\section{Future work}

User tests have already started and the platform will soon be available at the following address: www.checkyoursmile.fr. In the long term, we hope to develop new games, some of which in collaboration with the Innovalangues 2012-2018 IDEFI Project (Masperi \& Quintin, 2014). More generally, we are currently aiming at developing new sets of games based on mimes, gestures and imitation through the use of a webcam. We are for instance exploring the possibility of integrating gesture recognition in the platform as it has been demonstrated that hand gestures facilitate the acquisition of L2 vocabulary (e.g. Pavelin, 2002).

\section{Conclusion}

Cognitive ergonomics literature has taught us that no matter how innovative a tool is, it only starts to exist when it is used, i.e. to properly analyze a tool (or instrument), one needs to consider it in the context of its actual use (Rabardel, 1995). As a follow-up research study, we have assumed so far that students will be more involved and thus more motivated: as we said, this is a user-generated content database. Given that the use of the platform is part of the teaching scenario, the students will have to take part in the generation process of the content. This hypothesis will be tested in the near future, once the new version platform is up and running. Following research questions are thus inherent to computer assisted language learning; not whether an invention works but rather in which contexts it works or does not, and how and why (e.g. Bétrancourt, 2011). 


\section{Acknowledgements}

We would like to thank all the language teachers, colleagues from different fields, interns who made and are still making this project both a wonderful scientific and human experience. We would also like to thank the team of Lexicosciences for their collaboration and exchange of corpus data.

\section{References}

Barab, S., \& Squire, K. (2004). Design-based research: putting a stake in the ground. Journal of the Learning Sciences, 13(1), 1-14. https://doi.org/10.1207/s15327809j1s1301_1

Bétrancourt, M. (2011). Réflexion sur les technologies dans l'éducation et la formation: quelles pistes pour la recherche? (Rapport de Prospective pour la Recherche: éducation et Apprentissage à l'horizon 2030 (PREA 2K30)). Agence Nationale de la Recherche. http:// tecfa.unige.ch/perso/mireille/papers/Techno-Conditions.pdf

Cornillie, F., Thorne, S., \& Desmet, P. (2012). Editorial. Digital games for language learning: challenges and opportunities. ReCALL, 24(3), 243-256. https://oi.org/10.1017/S0958344012000134

Dornyei, Z. (2009). The psychology of second language acquisition. Oxford University Press.

Kessler, G. (2013). Collaborative language learning in co-constructed participatory culture. CALICO Journal, 30(3), 307-322. https://doi.org/10.11139/cj.30.3.307-322

Kim, Y. (2008). The contribution of collaborative and individual tasks to the acquisition of L2 vocabulary. The Modern Language Journal, 92(1), 114-130.

Masperi, M., \& Quintin, J.-J. (2014). L'innovation selon Innovalangues (E. D. Col, Éd.) Lingua e nuova didattica, (1/2014), 6-14.

Oblinger, D. G. (2004). The next generation of educational engagement. Journal of Interactive Media in Education, 2004(1). https://doi.org/10.5334/2004-8-oblinger

Papastergiou, M. (2009). Digital game-based learning in high school computer science education: impact on educational effectiveness and student motivation. Computers and Education, 52(1), 1-12. https://doi.org/10.1016/j.compedu.2008.06.004

Pavelin, B. (2002). Le geste à la parole. Toulouse : Presses Universitaires du Mirail.

Rabardel, P. (1995). Les hommes et les technologies: approche cognitive des instruments contemporains. U. Série Psychologie. Paris: Armand Colin.

Sarré, C., \& Whyte, S. (2016). Research in ESP teaching and learning in French higher education: developing the construct of ESP didactics. Asp, 69, 139-164. https://doi.org/10.4000/asp.4834

Sharples, M., McAndrew, P., Weller, M., Ferguson, R., FitzGerald, E., Hirst, T., \& Gaved, M. (2013). Innovating pedagogy 2013: exploring new forms of teaching, learning and assessment, to guide educators and policy makers ( No. 2). United Kingdom: The Open University. http://www.open.ac.uk/iet/main/sites/www.open.ac.uk.iet.main/files/files/ecms/ web-content/Innovating_Pedagogy_report_2013.pdf 
Thiagi. (n.d.). The 4Door ${ }^{\mathrm{TM}}$ eLearning approach. The Thiagi Group. http://www.thiagi.com/ games/2015/7/31/the-4door-elearning-approach

Van Der Yeught, M. (2014). Développer les langues de spécialité dans le secteur LANSAD Scénarios possibles et parcours recommandé pour contribuer à la professionnalisation des formations. Recherche et pratiques pédagogiques en langues de spécialité, 33(1), 12-32. https://doi.org/10.4000/apliut.4153 


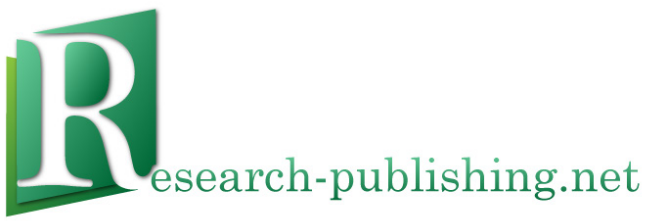

Published by Research-publishing.net, not-for-profit association Dublin, Ireland; Voillans, France, info@research-publishing.net

(C) 2016 by Editors (collective work)

(C) 2016 by Authors (individual work)

\section{CALL communities and culture - short papers from EUROCALL 2016 Edited by Salomi Papadima-Sophocleous, Linda Bradley, and Sylvie Thouësny}

Rights: All articles in this collection are published under the Attribution-NonCommercial -NoDerivatives 4.0 International (CC BY-NC-ND 4.0) licence. Under this licence, the contents are freely available online as PDF files (https://doi. org/10.14705/rpnet.2016.EUROCALL2016.9781908416445) for anybody to read, download, copy, and redistribute provided that the author(s), editorial team, and publisher are properly cited. Commercial use and derivative works are, however, not permitted.

\section{(9) $\Theta \Theta$}

Disclaimer: Research-publishing.net does not take any responsibility for the content of the pages written by the authors of this book. The authors have recognised that the work described was not published before, or that it is not under consideration for publication elsewhere. While the information in this book are believed to be true and accurate on the date of its going to press, neither the editorial team, nor the publisher can accept any legal responsibility for any errors or omissions that may be made. The publisher makes no warranty, expressed or implied, with respect to the material contained herein. While Research-publishing.net is committed to publishing works of integrity, the words are the authors' alone.

Trademark notice: product or corporate names may be trademarks or registered trademarks, and are used only for identification and explanation without intent to infringe.

Copyrighted material: every effort has been made by the editorial team to trace copyright holders and to obtain their permission for the use of copyrighted material in this book. In the event of errors or omissions, please notify the publisher of any corrections that will need to be incorporated in future editions of this book.

Typeset by Research-publishing.net

Cover design by (C) Easy Conferences, info@easyconferences.eu,www.easyconferences.eu

Cover layout by (c) Raphaël Savina (raphael@savina.net)

Photo "bridge" on cover by (C) Andriy Markov/Shutterstock

Photo "frog" on cover by (C) Fany Savina (fany.savina@gmail.com)

Fonts used are licensed under a SIL Open Font License

ISBN13: 978-1-908416-43-8 (Paperback - Print on demand, black and white)

Print on demand technology is a high-quality, innovative and ecological printing method; with which the book is never 'out of stock' or 'out of print'.

ISBN13: 978-1-908416-44-5 (Ebook, PDF, colour)

ISBN13: 978-1-908416-45-2 (Ebook, EPUB, colour)

Legal deposit, Ireland: The National Library of Ireland, The Library of Trinity College, The Library of the University of Limerick, The Library of Dublin City University, The Library of NUI Cork, The Library of NUI Maynooth, The Library of University College Dublin, The Library of NUI Galway.

Legal deposit, United Kingdom: The British Library.

British Library Cataloguing-in-Publication Data.

A cataloguing record for this book is available from the British Library.

Legal deposit, France: Bibliothèque Nationale de France - Dépôt légal: décembre 2016. 